\title{
Human Infections by Wohlfahrtiimonas chitiniclastica: A Mini-Review and the First Report of a Burn Wound Infection after Accidental Myiasis in Central Europe
}

\author{
Martin Hladík 1 ${ }^{(D)}$, Bretislav Lipovy ${ }^{1,2}$, Yvona Kaloudova ${ }^{1}$, Marketa Hanslianova ${ }^{3}$, Ivana Vitkova ${ }^{4}$, \\ Tereza Deissova ${ }^{5}$, Tomas Kempny ${ }^{1}$, Martin Svoboda ${ }^{6}$ D, Zdenek Kala ${ }^{6}$, Pavel Brychta ${ }^{1}$ \\ and Petra Borilova Linhartova $5,7, *$
}

1 Department of Burns and Plastic Surgery, Faculty of Medicine, Institution Shared with University Hospital Brno, Masaryk University, Jihlavská 20, 62500 Brno, Czech Republic; hladikm@gmail.com (M.H.); bretalipovy@gmail.com (B.L.); kaloudova.yvona@fnbrno.cz (Y.K.); tomas.kempny@gmail.com (T.K.); dr.brychta@seznam.cz (P.B.)

2 CEITEC-Central European Institute of Technology, Brno University of Technology, Purkyňova 656/123, 61200 Brno, Czech Republic

3 Department of Clinical Microbiology, Vyškov Hospital, Purkyňova 235/36, 62801 Vyškov, Czech Republic; hanslianova.marketa@nemvy.cz

check for

updates

Citation: Hladík, M.; Lipovy, B.; Kaloudova, Y.; Hanslianova, M.; Vitkova, I.; Deissova, T.; Kempny, T.; Svoboda, M.; Kala, Z.; Brychta, P.; et al. Human Infections by Wohlfahrtiimonas chitiniclastica: A Mini-Review and the First Report of a Burn Wound Infection after Accidental Myiasis in Central Europe. Microorganisms 2021, 9, 1934. https://doi.org/10.3390/ microorganisms 9091934

Academic Editors: Dominic Wichmann and Jörn Grensemann

Received: 24 August 2021

Accepted: 9 September 2021

Published: 11 September 2021

Publisher's Note: MDPI stays neutral with regard to jurisdictional claims in published maps and institutional affiliations.

Copyright: (c) 2021 by the authors. Licensee MDPI, Basel, Switzerland. This article is an open access article distributed under the terms and conditions of the Creative Commons Attribution (CC BY) license (https:/ / creativecommons.org/licenses/by/ $4.0 /)$.
4 Department of Clinical Microbiology and Immunology, University Hospital Brno, Jihlavská 20, 62500 Brno, Czech Republic; vitkova.ivana@fnbrno.cz

5 Environmental Genomics Research Group, RECETOX, Faculty of Science, Masaryk University, Kamenice 5 , 62500 Brno, Czech Republic; tdeiss@mail.muni.cz

6 Department of Surgery, Faculty of Medicine, Institution Shared with University Hospital Brno, Masaryk University, Jihlavská 20, 62500 Brno, Czech Republic; svoboda.martin2@fnbrno.cz (M.S.);

kala.zdenek@fnbrno.cz (Z.K.)

7 Clinic of Maxillofacial Surgery, Faculty of Medicine, Institution Shared with the University Hospital Brno, Masaryk University, Jihlavská 20, 62500 Brno, Czech Republic

* Correspondence: petra.linhartova@recetox.muni.cz

Abstract: Wohlfahrtiimonas chitiniclastica are bacteria that cause rare infections, typically associated with the infestation of an open wound with fly larvae. Here, we present a unique case report of the first $W$. chitiniclastica isolation from a burn wound with accidental myiasis in a 63-year-old homeless man and a literature review focused on human infections caused by these bacteria. So far, 23 cases of infection with $W$. chitiniclastica have been reported; in $52 \%$ of these, larvae were found in the wound area. Most of these cases suffered from chronic non-healing wound infections but none of these were burn injuries. The overall fatality rate associated directly with $W$. chitiniclastica in these cases was $17 \%$. Infections with parasitic larvae occur in moderate climates (especially in people living in poor conditions); therefore, an infection with rare bacteria associated with accidental myiasis, such as W. chitiniclastica, can be expected to become more common there. Thus, in view of the absence of recommendations regarding the treatment of patients with accidental myiasis and, therefore, the risk of infection with $W$. chitiniclastica or other rare pathogens, we provide a list of recommendations for the treatment of such patients. The importance of meticulous microbial surveillance using molecular biological methods to facilitate the detection of rare pathogens is emphasized.

Keywords: Wohlfahrtiimonas chitiniclastica; burn wound infection; myiasis

\section{Introduction}

Wohlfahrtiimonas chitiniclastica was first described in 2008 by Tóth et al. [1]. These bacteria are strictly aerobic gram-negative, straight short rods $(1.5-2.0 \times 0.5-1.0 \mu \mathrm{m})$ that are non-motile, non-spore-forming, which grow at $\mathrm{pH} 5.0-10.5$ and temperatures of $28-37^{\circ} \mathrm{C}$, and are capable of causing both local skin/soft tissues infections (SSTIs) and sepsis. $W$. chitiniclastica is catalase and oxidase-positive, and indole, urease and $\mathrm{H}_{2} \mathrm{~S}$ negative. It has a 
strong chitinase activity, which leads to discussions about whether or not its presence can be symbiotic and play a role in the larval metamorphosis [1,2].

The presence of $W$. chitiniclastica was associated with fly larvae infestation in open wounds; nevertheless, an infection with this bacterium is very rare in humans [2]. In the last decade, rare pathogens have begun to emerge as causes of the development of infectious complications. To date, there is no report about a W. chitiniclastica infection in a burn wound [3].

This paper describes the first isolation worldwide of $W$. chitiniclastica from a burn wound with accidental myiasis (interestingly in a patient from Central Europe) and reviews available information on $W$. chitiniclastica-caused infections in humans. In addition, a set of recommendations for care of a patient with accidental myiasis and, therefore, a possible infection with $W$. chitiniclastica and other rare pathogens, is proposed.

\section{Case Report}

We describe the case of a 63-years-old man who was transferred to the Department of Burns and Plastic Surgery of the University Hospital Brno, Czech Republic, with deep burns in the region of thorax and abdomen, covering $5 \%$ of the total body surface area (TBSA). His vitals on admission showed a body temperature of $37.2{ }^{\circ} \mathrm{C}$, blood pressure of $163 / 87 \mathrm{mmHg}$, and a heart rate of $98 / \mathrm{min}$. On admission, the patient suffered from massive cutaneous myiasis, pediculosis of the head, and phlegmon of the thorax. The patient lived in poor and unhygienic conditions (homeless/staying in shelters for homeless people overnight). He admitted to tobacco and alcohol abuse; he also had hepatitis A in the past. He reported that his burns were the result of an injury that happened two weeks prior, when his shirt caught fire while smoking a cigarette. Right after the injury, first aid was provided by the shelter employee. For the next two weeks, however, the wound was left unattended. The wound showed signs of accidental myiasis, redness, and edema (Figure 1).
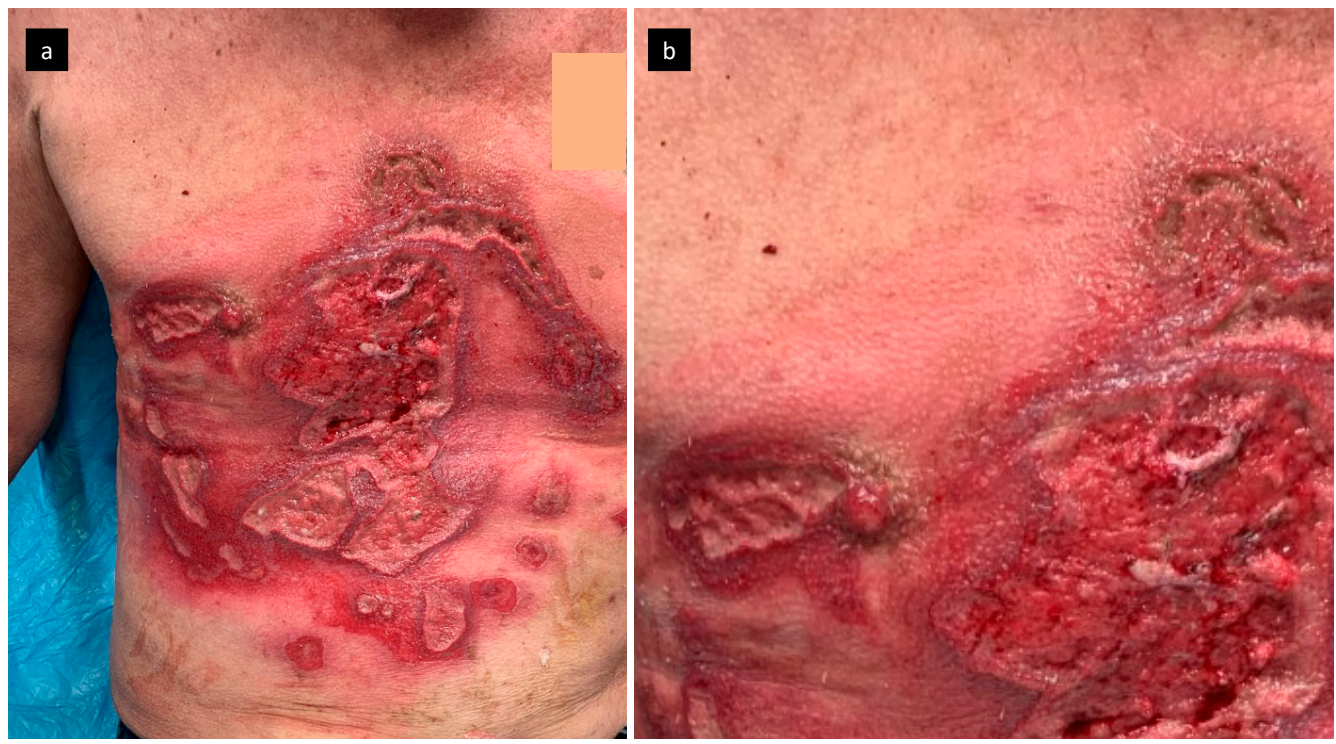

Figure 1. The wound on admission after removal of maggots with signs of redness and edema (a), in detail (b).

The maggot infestation was immediately mechanically removed, and swabs were taken for microbiological analysis. Local therapy included Octenisept ${ }^{\circledR}$ (Schülke \& Mayr $\mathrm{GmbH}$, Norderstedt, Germany) for antisepsis and Flamazine ${ }^{\circledR}$ cream $1 \% w / w$ (Smith \& Nephew Pharmaceuticals Ltd., Hessle Road, Hull, UK) for wound-bed preparation; at the same time, systemic oral therapy with amoxicillin, clavulanic acid ( $1 \mathrm{~g}$ every $8 \mathrm{~h}$ ) and metronidazole (500 mg every $8 \mathrm{~h}$ ) was initiated. Dressings were changed every 2 days; 
no maggots were observed after the first infestation removal and the wound bed was prepared for closure. Staphylococcus aureus, Streptococcus pyogenes, and W. chitiniclastica were isolated from the initial swab, all susceptible to amoxicillin and clavulanic acid. On day 7, debridement under general anesthesia was performed and defects were finally covered with split-thickness skin grafts on 3\% TBSA (Figure 2).

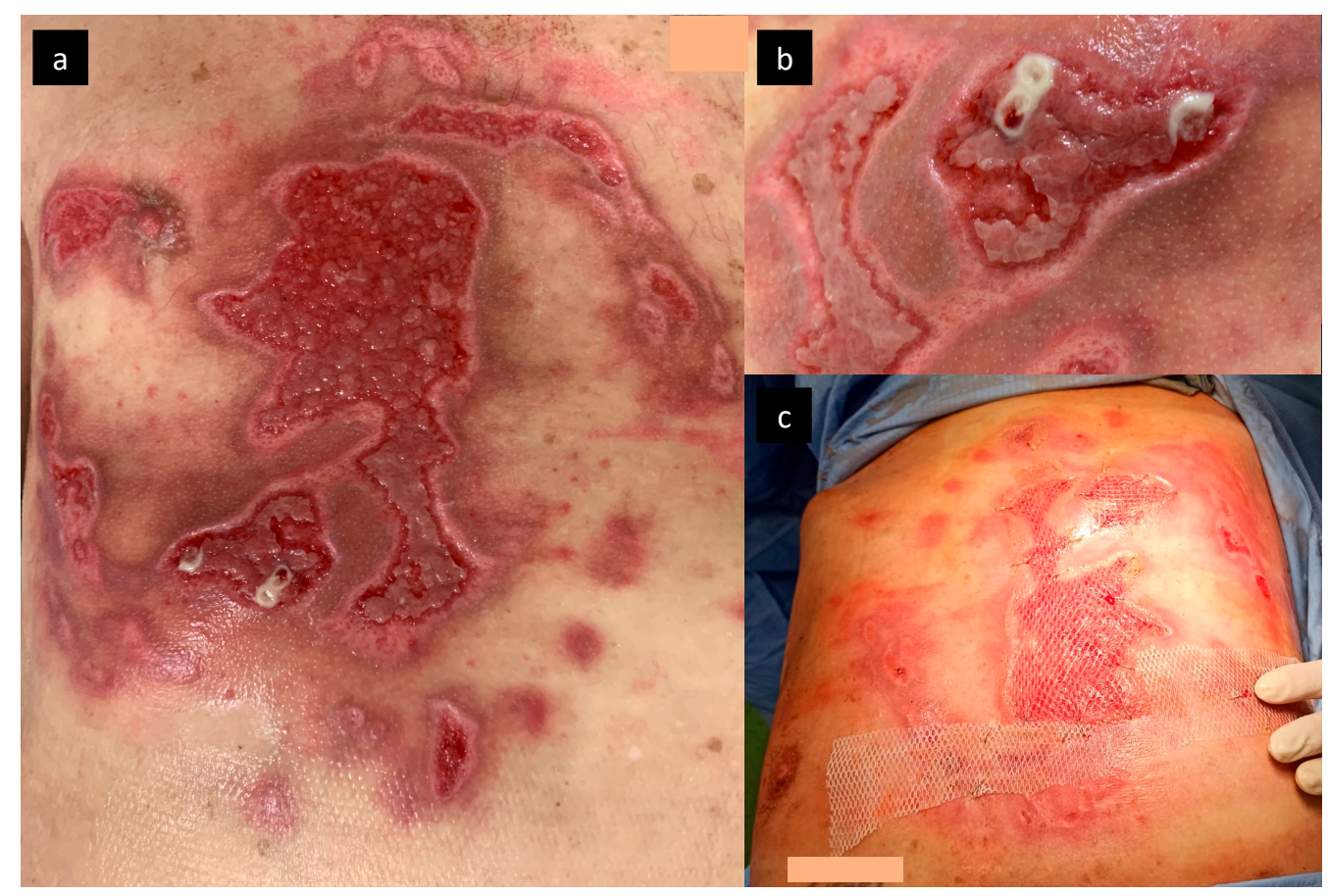

Figure 2. Wound bed preparation with granulation tissue $(\mathbf{a}, \mathbf{b})$, the process of split-thickness skin graft transplantation (c).

The next series of swabs revealed only coagulase-negative Staphylococcus in a single spot; hence, the systemic therapy with amoxicillin and clavulanic acid continued for 8 days. All skin defects were completely healed, and the patient was discharged to our outpatient care and long-term care ward for intensive rehabilitation (Figure 3).

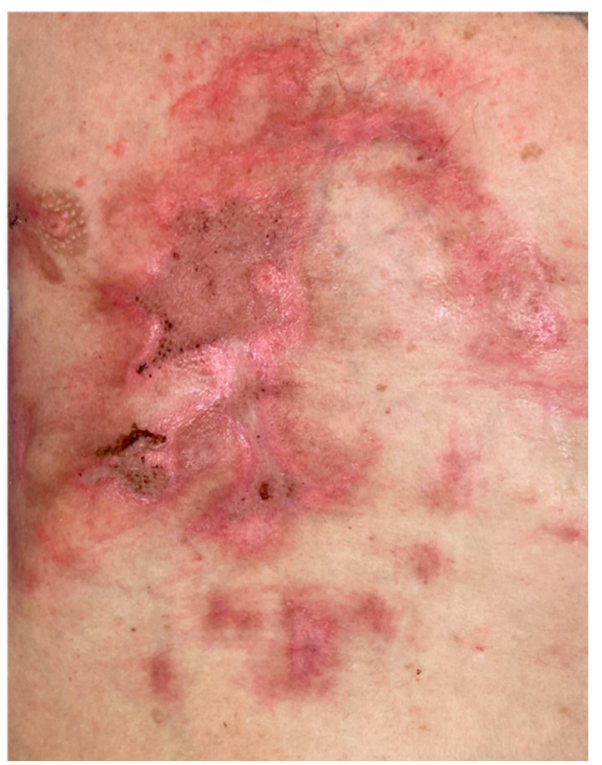

Figure 3. Complete burn wound closure on the discharge of the patient. 


\subsection{Pathogen Identification}

As a part of the microbiological examinations, swabs from the patient's burn areas were transferred to culture media suitable for both aerobic and anaerobic growth; blood agar (Merck KGaA, Darmstadt, Germany), McConkey agar (selective medium for growth of gram-negative bacteria; Pronadisa, Conda Laboratories, Madrid, Spain) and blood agar with $\mathrm{NaCl}$ addition (selective agar for staphylococci; Merck KGaA, Germany) were used for aerobic culture and VL agar (Bio-Rad Laboratories Chemical Division, Richmond, CA, USA) was used for anaerobic culture. The inoculated culture media were then incubated for 18-24 $\mathrm{h}$ at $35-37^{\circ} \mathrm{C}$; blood agar and chocolate agar (OXOID CZ, Brno, Czech Republic) in the atmosphere with elevated $\mathrm{CO}_{2}$ concentration, $\mathrm{VL}$ agar in the anaerobic atmosphere, and the remaining media in a normal atmosphere. The growth of the $W$. chitiniclastica strain on the culture media and the morphology of the individual colonies are shown in Figure 4.
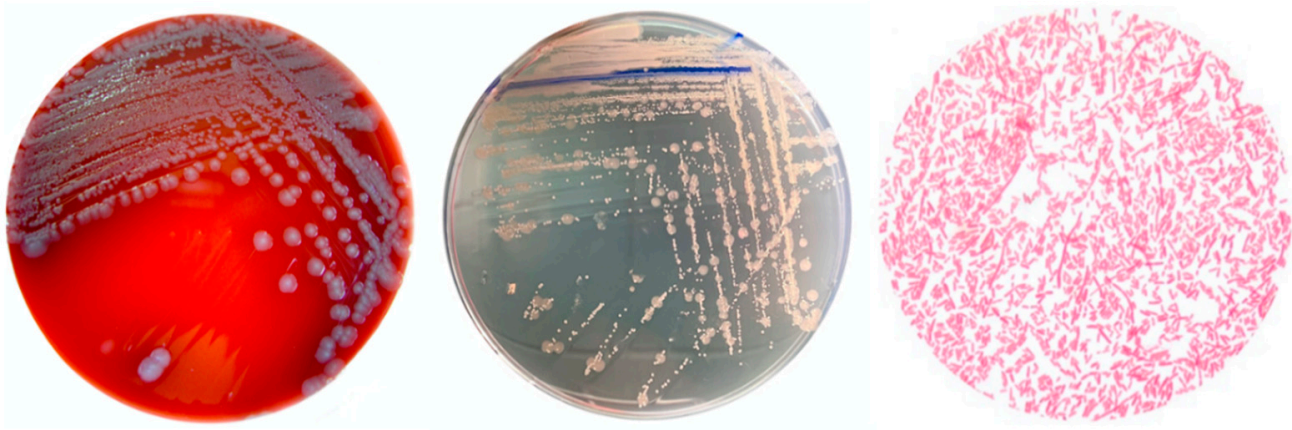

Figure 4. Wohlfahrtiimonas chitiniclastica colonies on blood agar (Merck KGaA, Germany) and nonselective chromogenic agar (UriSelect, Bio-Rad Laboratories, Hercules, CA, USA) (left, center). Microscopic view of the morphology of W. chitiniclastica (right). Olympus BX40 microscope, Olympus Czech group, s.r.o., magnification $100 \times$. The specimen is stained according to Gram.

The colonies were then identified using the MALDI-TOF Biotyper (Bruker Daltonics, GmbH, Leipzig, Germany) and software MALDI TOF MS, version 3.1.

In addition, bacterial DNA obtained from the culture of W. chitiniclastica was isolated by the QIAamp BiOstic Bacteremia DNA Kit (QIAGEN Redwood City, CA, USA). DNA was analyzed by the 16S rRNA Sanger sequencing method (SEQme s.r.o., Dlouha 176 26,301 Dobris, Czech Republic), forward primer 5'-AYTGGGYDTAAAGNG-3' and reverse primer 500B4-CCGTCAATTYYTTTRAGTTT- $3^{\prime}$ were used. A 98\% match of the specified sequence with the sequence of $W$. chitiniclastica DSM 18,708 strain S5 16S rRNA was found using the basic local alignment search tool (BLAST) provided by the National Center for Biotechnology Information (NCBI) [4] (Figure 5).

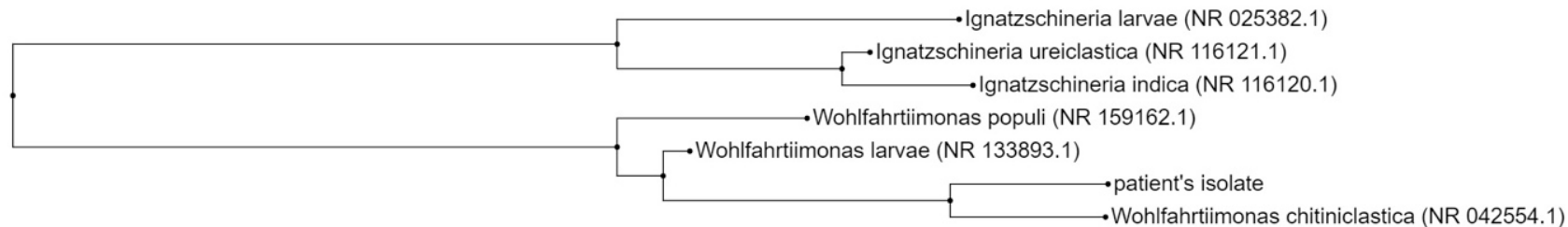

Figure 5. Neighbor-joining phylogenetic tree of partial 16S rRNA gene sequences. Sequences from GenBank are shown with taxonomic names (sequence ID). Query_57927 is the sequence of the patient's isolate. 


\subsection{Antimicrobial Susceptibility Profile of W. chitiniclastica}

The susceptibility of $W$. chitiniclastica to antibiotics was established by determining the minimum inhibitory concentration using the MicroScan WalkAway MIC instrument (Beckman Coulter, Brea, CA, USA). Susceptibilities were evaluated using a disc diffusion method according to the EUCAST standard-PK/PD (non-species related) breakpoints (EUCAST Clinical Breakpoints Tables, v.10.0, January 2020). The W. chitiniclastica strain was sensitive to the tested antibiotics, including the amoxicillin/clavulanate used in the therapy (Table 1).

Table 1. Susceptibility of the isolated Wohlfahrtiimonas chitiniclastica according to the EUCAST Clinical Breakpoints.

\begin{tabular}{ccc}
\hline Antibiotic & MIC Value (mg/L) & Interpretation \\
\hline Amoxicillin/clavulanic acid & $<2.0$ & $\mathrm{~S}$ \\
Piperacillin/tazobactam & $<4.0$ & $\mathrm{~S}$ \\
Cefotaxime & 1.0 & $\mathrm{~S}$ \\
Ceftazidime & $<0.5$ & $\mathrm{~S}$ \\
Cefepime & $<0.5$ & $\mathrm{~S}$ \\
Ciprofloxacin & 0.25 & $\mathrm{~S}$ \\
Levofloxacin & 0.5 & $\mathrm{~S}$ \\
Ofloxacin & 0.25 & $\mathrm{~S}$ \\
Imipenem & $<1.0$ & $\mathrm{~S}$ \\
Meropenem & $<0.5$ & $\mathrm{~S}$ \\
\hline
\end{tabular}

S: sensitive; MIC: minimum inhibition concentration.

\section{Review and Discussion}

Myiasis (from the Greek myia, which means fly, and iasis, disease) is defined as an infestation of humans or other vertebrates with a larval stage of an insect. The term was first used by F. W. Hope in 1840, who used it to distinguish diseases caused by the larvae of dicotyledons from other parasitic insects [5]. Such larvae are usually detected in necrotic tissue (benign myiasis), but can also affect fully viable tissue (malignant myiasis). In the past, myiasis was almost exclusively described in tropical or subtropical climates [6]. In recent years, it has also been found in temperate climates [6].

Two principal types of myiasis can be distinguished, controlled and accidental. Controlled myiasis is a therapeutic procedure using sterile larvae for selective debridement of necrotic tissue and facilitation of the wound-healing phase. This methodology is mainly used in the treatment of non-healing wounds. Larvae can also be used for reducing the bioburden of gram-positive strains of bacteria. In modern times, this method was first approved for use in 2004 by the Food and Drug Administration [7].

Accidental myiasis usually arises as a manifestation of parasitic larvae in non-healing wounds in high-risk groups of patients (alcohol addiction, homelessness, poor hygiene, tobacco use, chronic vascular diseases, immunocompromisation, non-compliant patients, low socioeconomic status, etc.). Our patient had almost all of these risk factors (he was a homeless, alcohol and tobacco abuser with poor living conditions). His burns were not treated and covered with any dressings for 2 weeks prior to hospitalization (hence the notion of non-compliancy). In accidental myiasis, the larvae are not sterile and, therefore, can act as a vector for a variety of potentially pathogenic microorganisms, such as $W$. chitiniclastica or Ignatzschineria indica.

Accidental myiasis causing bacteremia or sepsis can be potentially lethal. So far, there is no uniform therapeutic concept or methodology for sanitizing the primary larval burden. In the case of cavital myiasis, surgical intervention involving incision and drainage, or the excision of infected tissue may be necessary. In the case of cutaneous myiasis, manual debridement with removal of the larvae is needed; in the case of deeper penetration with larvae, their primary asphyxiation with petroleum jelly or similar material is a suitable method for their eradication. 
Burn patients are highly susceptible to infections in the area of the skin defect; infectious complications account at present for the majority of mortality and morbidity in these patients. Immediately after thermal trauma, any burn area is sterile as a result of the heat on the superficial microorganisms. However, the necrotic tissue in the wound bed represents an excellent growth medium for microorganisms, especially for bacteria with a short generation time. Burn wound infections are relatively diverse, ranging from cellulitis and impetigo to invasive wound infections requiring prompt antimicrobial treatment with early debridement [8]. In our patient, we used manual debridement with the removal of larvae and antiseptic treatment.

In the course of thermal trauma therapy, both quantitative and qualitative changes in microbial colonization occur in the burn area (as well as in the other parts of the body). While etiologically, gram-positive cocci (S. aureus, coagulase-negative Staphylococci, Streptococcus sp., etc.) predominated the burn wound in the first week of hospitalization, the predominance of gram-negative rods (mainly representatives of Enterobacteriacae sp., Pseudomonas aeruginosa, Acinetobacter baumannii, etc.) begins to manifest from the second week of hospitalization onwards [9]. Rare viral, bacterial, and yeast infections in burn patients occur mostly as a result of the encounter with microorganisms of exogenous origin [10]. The burn wound infection in our patient with minor burns was of polymicrobial etiology; interestingly, W. chitiniclastica was cultured from the burn wound, which was also confirmed by the sequencing analysis. It should be mentioned that $W$. chitiniclastica was cultured on blood agar in an elevated $\mathrm{CO}_{2}$ concentration, which falls within a standard set of culture conditions; therefore, no special culture is necessary.

W. chitiniclastica can be found in Wohlfahrthia magnifica (Diptera, Sarcophagidae) a parasitic flesh fly native to continental Europe, Asia and the Mediterranean, Lucilia sericata (green bottle fly) in the Americas, Chrysomya megacephala (oriental latrine fly), Hermetia illucens (black soldier fly), and Musca domestica L. (housefly) [7,11,12]. Although most reports of $W$. chitiniclastica infections have been associated with the larvae of parasitic flies, this bacterium has also been isolated in retail frozen chicken meat, arsenic-affected soils in Bangladesh, and in cow [13-15].

Despite the fact that W. magnifica is the most likely vector of this myiasis in the Czech Republic, another possible vector, a new invasive representative of the order Diptera, Clogmia albipunctata, has been also reported in the geographical area where our patient resided [16]. The identification of the vector was not performed in our case. Although it is not important for clinical practice, it may be perceived as a limitation of this paper from the epidemiological perspective. If a particular vector overpopulation occurs in a certain area, we can potentially expect an increased risk of rare pathogen infections, including $W$. chitiniclastica. For this reason, we would also like to recommend the determination of the vector, where possible, in any future cases of myiasis, especially if a rare pathogen is identified. This can be performed, for example, by inserting the larvae into a fixation solution and if a rare pathogen is determined, cooperation with entomologists can be initiated.

Most reports of $W$. chitiniclastica infections originate from subtropical or tropical regions [2,11,17-32] (see the literature review in Table 2). Nevertheless, an infection with bacterium was also reported from northern Europe [18]. Similarly, our case did not occur in subtropical or tropical conditions either, but in a moderate climate in the autumn with relatively low day temperatures (the mean temperature at our patient's place of residence between the accident and hospitalization was $14.13 \pm 3.75^{\circ} \mathrm{C}$ ). This supports the notion that living conditions are extremely important for the development of W. chitiniclastica. 
Table 2. Review of the literature of case reports; human infections caused by Wohlfahrtiimonas chitiniclastica.

\begin{tabular}{|c|c|c|c|c|c|c|c|c|}
\hline $\begin{array}{l}\text { Year } \\
\text { [Ref.] }\end{array}$ & Country & $\begin{array}{l}\text { Sex/age } \\
\text { Years }\end{array}$ & Culture Site & Anatomic Localization & $\begin{array}{l}\text { Associated } \\
\text { Myiasis }\end{array}$ & Antibiotics & Outcome & Associated Bacteria \\
\hline 2009 [2] & France & $\mathrm{F} / 60$ & Blood culture & Scalp(head) & Yes & ceftriaxon & Survived & - \\
\hline 2011 [17] & Argentina & $\mathrm{M} / 70$ & Blood culture & Inguinal regions & No & $\begin{array}{l}\text { ciprofloxacin }+ \\
\text { ampicillin-sulbactam and later } \\
\text { ceftazidime }+ \text { amikacin }\end{array}$ & Died & \\
\hline 2014 [18] & Estonia & $\mathrm{M} / 64$ & Resected bone & Right foot & No & amoxicillin-clavulonate & Survived & MYOD \\
\hline 2015 [19] & India & $\mathrm{M} / 43$ & Ulcer swab & Right lower limb ulcer & No & $\begin{array}{l}\text { cefoperazone-sulbactam followed } \\
\text { by cefpodoxime (outpatient care) }\end{array}$ & Survived & \\
\hline 2015 [20] & USA & $\mathrm{M} / 26$ & Ulcer swab & Right leg & No & cefpodoxime & Survived & PRVU, KLPN, MSSA \\
\hline 2015 [21] & UK & $\mathrm{F} / 82$ & Blood culture & $\begin{array}{l}\text { Excoriations of head, } \\
\text { face, and neck }\end{array}$ & Yes & $\begin{array}{l}\text { cefuroxime, metronidazole, } \\
\text { clarithromycin, topical } \\
\text { chloramphenicol, fucidic acid } \\
\text { followed by flucloxacillin } \\
\text { (outpatient care) }\end{array}$ & Survived & PRMI, PRRE, MSSA \\
\hline 2016 [22] & USA & $\begin{array}{l}\mathrm{F} / 69 \\
\mathrm{M} / 72\end{array}$ & $\begin{array}{l}\text { F/Ulcer swab } \\
\text { M/blood culture }\end{array}$ & $\begin{array}{l}\text { F/Sacral decubitus } \\
\text { M/Right foot and } \\
\text { umbilical wound }\end{array}$ & $\begin{array}{l}\text { F/No } \\
\text { M/Yes }\end{array}$ & $\begin{array}{l}\text { F/ceftaroline fosamil, } \\
\text { meropenem, } \\
\text { amoxicillin-clavulonate } \\
\text { (outpatient care) } \\
\text { M/piperacilline-tazobactam, } \\
\text { vancomycin, clindamycin }\end{array}$ & $\begin{array}{l}\text { F/Survived } \\
\text { M/Died }\end{array}$ & $\begin{array}{l}\text { F/Blood culture: ANSU } \\
\text { Urine: PRMI } \\
\text { Decubitus: MSSA, } \\
\text { AEspp., STspp., BAFR } \\
\text { M/ESCO }\end{array}$ \\
\hline 2016 [23] & South Africa & $\mathrm{M} / 17$ & Blood culture & Right shoulder wound & No & ceftriaxone & Survived & \\
\hline $2017[24]$ & Germany & $\begin{array}{l}\mathrm{F} / 78 \\
\mathrm{M} / 43 \\
\mathrm{M} / 71 \\
\mathrm{M} / 79\end{array}$ & $\begin{array}{l}\text { F/78 Swabs from ulcers } \\
\text { M/43 Swabs from ulcers } \\
\text { M/71 Swabs from ulcers } \\
\text { M/79 Swab from ulcer }\end{array}$ & $\begin{array}{l}\text { F/78 Leg ulcer } \\
\text { M/43 Leg ulcer } \\
\text { M/71 Leg ulcer } \\
\text { M/79 Leg ulcer }\end{array}$ & $\begin{array}{l}\text { No } \\
\text { No } \\
\text { No } \\
\text { No }\end{array}$ & $\begin{array}{l}\text { F/78 no antibiotic treatment } \\
\mathrm{M} / 43 \text { no antibiotic treatment } \\
\mathrm{M} / 71 \text { no antibiotic treatment } \\
\mathrm{M} / 79 \text { cefuroxime followed by } \\
\text { levofloxacin and clindamycin }\end{array}$ & $\begin{array}{l}\text { F/78 Survived } \\
\text { M/43 Survived } \\
\text { M/71 Survived } \\
\text { M/79 Survived }\end{array}$ & $\begin{array}{l}\text { F/78 PRMI, MSSA, } \\
\text { SEMA, MOMO } \\
\text { M/43 PRMI } \\
\text { M/71 PRMI, PRST, PSAE } \\
\text { M/79: ESCO }\end{array}$ \\
\hline 2017 [25] & USA & $\mathrm{F} / 41$ & $\begin{array}{l}\text { Blood culture and } \\
\text { decubitus swab }\end{array}$ & $\begin{array}{l}\text { Ischial decubitus or } \\
\text { lower extremity bilateral } \\
\text { excoriations }\end{array}$ & No & $\begin{array}{l}\text { vancomycin, cefepim, } \\
\text { metronidazole }\end{array}$ & $\begin{array}{l}\text { Died due to other } \\
\text { disease }\end{array}$ & $\begin{array}{l}\text { Blood culture: PRMI } \\
\text { Swab: MYIN, ENFA } \\
\text { ENFA, BAspp. }\end{array}$ \\
\hline 2017 [11] & Malaysia & $\mathrm{F} / 47$ & Blood culture & - & No & cefoperazone & $\begin{array}{l}\text { Died due to other } \\
\text { disease }\end{array}$ & \\
\hline 2018 [26] & USA & $\mathrm{M} / 37$ & Blood culture & $\begin{array}{l}\text { Left lower extremity } \\
\text { ulcer }\end{array}$ & Yes & $\begin{array}{l}\text { piperacilline-tazobactam, } \\
\text { vancomycin, clindamycin later } \\
\text { cefepime }\end{array}$ & Survived & PRST, IGIN \\
\hline 2018 [27] & Japan & $\mathrm{M} / 75$ & Blood culture & Left shoulder lesion & Yes & $\begin{array}{l}\text { vancomycin, cefepime, } \\
\text { metronidazole }\end{array}$ & Survived & $\begin{array}{l}\text { MOMO, STspp., BAspp., } \\
\text { PRMI }\end{array}$ \\
\hline
\end{tabular}


Table 2. Cont

\begin{tabular}{|c|c|c|c|c|c|c|c|c|}
\hline $\begin{array}{c}\text { Year } \\
\text { [Ref.] }\end{array}$ & Country & $\begin{array}{c}\text { Sex/age } \\
\text { Years }\end{array}$ & Culture Site & Anatomic Localization & $\begin{array}{l}\text { Associated } \\
\text { Myiasis }\end{array}$ & Antibiotics & Outcome & Associated Bacteria \\
\hline 2018 [28] & USA & $\mathrm{M} / 57$ & Blood culture & Right ankle gangrene & Yes & Not stated & Died & PRAC, CNS \\
\hline 2019 [29] & Australia & $\mathrm{M} / 54$ & Blood culture & Right foot wound & Yes & $\begin{array}{l}\text { piperacilline-tazobactam + } \\
\text { meropenem, ciprofloxacin } \\
\text { (outpatient care) }\end{array}$ & Survived & MOMO \\
\hline 2019 [30] & USA & $\begin{array}{l}\mathrm{M} / 63 \\
\mathrm{~F} / 87\end{array}$ & $\begin{array}{l}\text { M/blood culture } \\
\text { F/swab }\end{array}$ & $\begin{array}{l}\text { M/Right foot ulcer } \\
\text { F/Left lower extremity } \\
\text { wound }\end{array}$ & $\begin{array}{l}\text { Yes } \\
\text { Yes }\end{array}$ & $\begin{array}{l}\text { M/vancomycin+ } \\
\text { piperacilin/tazobactam } \\
\text { F/unknown }\end{array}$ & $\begin{array}{l}\text { M/Died } \\
\text { F/unknown }\end{array}$ & $\begin{array}{l}\text { M/PRRE } \\
\text { F/- }\end{array}$ \\
\hline 2021 [32] & USA & $\mathrm{M} / 70$ & Blood culture & $\begin{array}{l}\text { Ulcer of left temporal } \\
\text { region }\end{array}$ & Yes & levofloxacin & Survived & MSSA, PRMI \\
\hline
\end{tabular}

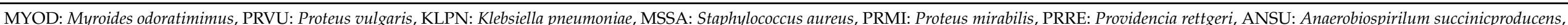

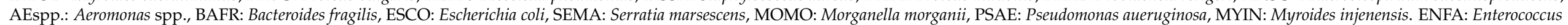

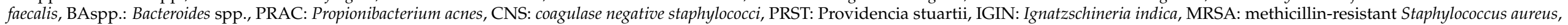
STspp.: Streptococcus spp. 
The spectrum of infections in the total of the 23 reported patients ranges from wound infection (43\% of all reported patients) to bacteremia or bloodstream infection (61\% of all reported patients). In some cases, the infection might have resulted in septic shock; however, we are not aware of any reported case of burn wound or other acute wound infection. Most reported cases described secondary infections in patients with non-healing wounds (34\% of patients reported). Although infection with $W$. chitiniclastica is generally considered to be associated with maggot infestation, no larvae were identified in the wound area in $48 \%$ of the described cases.

The mortality associated with this type of infectious complication depends on the host condition and immunological status, but also on the level of invasiveness/severity of the infection itself and, of course, the quality of care. The overall fatality rate reported in previous studies was $26 \%$; however, death clearly associated with $W$. chitiniclastica infection was reported only in $17 \%$ of patients (all of whom had an invasive infection). Only six patients $(26 \%)$ described in the literature suffered from a monobacterial $W$. chitiniclastica infection; the remaining 17 (74\%) were infected with multiple pathogens. This was also the case of our patient who presented with multiple pathogens (besides W. chitiniclastica, $S$. aureus, and S. pyogenes were also detected in the burn wound).

Since infection with $W$. chitiniclastica is very rare, no standardized antimicrobial protocol for its treatment has been established so far. The most commonly used antibiotics in the treatment of such infections include beta-lactams (mainly amoxicillin-clavulonate, cefuroxime, ceftriaxone, or cefepime) or fluoroquinolones (ciprofloxacin, levofloxacin).

The situation is further complicated by the fact that, as mentioned above, many of the cases described in the literature are not monopathogenic infections; therefore, all pathogens present in the wound must be taken into consideration. Therefore, we recommend the following when encountering a patient with accidental myiasis (and with an increased possibility of infection with $W$. chitiniclastica or other rare pathogens):

1. Larvae should be removed from the wound (cutaneous myiasis); non-invasive removal of larvae is possible by occlusion or suffocation using petroleum jelly, beeswax, or liquid paraffin. Over the course of several hours, the larvae either leave the wound or die and can be removed more easily from the wound [33]. Surgical removal of larvae requires repeated debridement with an application of antiseptic agents. In the case of cavitary myiasis, surgical debridement, incision or even excision of the infected tissue may be necessary [6]. The larvae should be also preserved for potential future identification;

2. Microbiological analysis focusing on the bacteria typically associated with accidental myiasis should be performed (e.g., Proteus mirabilis, Ignatzschineria indica, Providencia rettgeri, Morganella morganii, and Staphylococcus aureus). For the identification of rare pathogens, especially W. chitiniclastica, MALDI-TOF MS or 16S rRNA sequencing are recommended $[17,22,24]$ because the use of the VITEK 2 system often leads to misclassification: for example, W. chitiniclastica was incorrectly classified as Acinetobacter lwoffii, Comamonas testosteroni or Rhizobium radiobacter [18,20,25]. As no data are available on the performance of other systems, a study evaluating the performance of other methods with respect to the identification of $W$. chitiniclastica can be valuable for clinical practice;

3. The choice of antimicrobial therapy should be tailored to the overall microbiological findings; management should also be based on the severity of the infectious complication.

\section{Conclusions}

Accidental myiasis is no longer the domain of only subtropical or tropical regions; with climate change, the likelihood of its occurrence, especially in people with low socioeconomic status, increases in temperate climates as well. In individuals with unsterile parasitic larvae infestation, infection by rare pathogens, such as $W$. chitiniclastica, can be suspected. To minimize the impact of potential septic complications on the patient, the 
rapid and accurate identification of microorganisms using molecular-biological methods, followed by effective antimicrobial therapy, is necessary.

Author Contributions: Conceptualization, M.H. (Martin Hladik), B.L. and P.B.L.; methodology, B.L. and P.B.L.; validation, M.H. (Martin Hladik), B.L. and P.B.L.; formal analysis, M.H. (Martin Hladik), B.L. and P.B.L.; investigation, M.H. (Martin Hladik), B.L., T.D. and P.B.L.; resources, M.H. (Martin Hladik) and B.L.; data curation, B.L., P.B.L. and M.H. (Marketa Hanslianova); writing-original draft preparation, M.H. (Martin Hladik), B.L., P.B.L. and M.H. (Marketa Hanslianova); writing-review and editing, M.H. (Martin Hladik), B.L., Y.K., M.H. (Marketa Hanslianova), I.V., T.D., T.K., M.S., Z.K., P.B. and P.B.L.; supervision, B.L. and P.B.L.; project administration, B.L.; funding acquisition, B.L. All authors have read and agreed to the published version of the manuscript.

Funding: The study was supported by the Ministry of Health of the Czech Republic, grants No. NV19-05-00214 and No. NU20-05-00166. This project has received funding from the European Union's Horizon 2020 research and innovation program under grant agreement No 857560. All rights reserved.

Institutional Review Board Statement: The Ethics Committee for Multicentre Clinical Trials of the University Hospital Brno approved this publication (18-091220/EK, 9 December 2020). All the procedures performed in this case presentation were in accordance with the ethical standards of the institutional and/or national research committee and with the 1964 Helsinki Declaration and its later amendments or comparable ethical standards. Informed consent was obtained from the patient.

Informed Consent Statement: Informed consent was obtained from the subject involved in the study.

Data Availability Statement: Data supporting presented results are available upon request.

Conflicts of Interest: The authors declare no conflict of interest.

\section{References}

1. Tóth, E.M.; Schumann, P.; Borsodi, A.; Kéki, Z.; Kovács, A.L.; Márialigeti, K. Wohlfahrtiimonas chitiniclastica gen. nov., sp. nov., a new gammaproteobacterium isolated from Wohlfahrtia magnifica (Diptera: Sarcophagidae). Int. J. Syst. Evol. Microbiol. 2008, 58, 976-981. [CrossRef]

2. Rebaudet, S.; Genot, S.; Renvoise, A.; Fournier, P.-E.; Stein, A. Wohlfahrtiimonas chitiniclasticaBacteremia in Homeless Woman. Emerg. Infect. Dis. 2009, 15, 985-987. [CrossRef]

3. Lipový, B.; Brychta, P.; Řihová, H.; Hanslianová, M.; Loskotová, A.; Jarkovský, J.; Kaloudová, Y.; Suchánek, I. Prevalence of Infectious Complications in Burn Patients Requiring Intensive Care: Data from a Pan-European Study. Epidemiol. Microbiol. Imunol. 2016, 65, 25-32.

4. U.S. National Library of Medicine: National Center for Biotechnology Information. Available online: https://blast.ncbi.nlm.nih. gov /Blast.cgi?PROGRAM=blastn\&PAGE_TYPE=BlastSearch\&LINK_LOC=blasthome (accessed on 20 August 2021).

5. Hope, F.W. On Insects and Thein Larva Occasionally Found in the Human Body, 2nd ed.; Transactions Royal Entomological Society: London, UK, 1840; pp. 256-271.

6. Gour, S.; Ramesh, G.; Kumar, V.; Thapliyal, G.K.; Nagarajappa, R. Cavitary myiasis and its management. J. Exp. Ther. Oncol. 2018, 12, 211-216. [PubMed]

7. Bazaliński, D.; Kózka, M.; Karnas, M.; Więch, P. Effectiveness of Chronic Wound Debridement with the Use of Larvae of Lucilia Sericata. J. Clin. Med. 2019, 8, 1845. [CrossRef] [PubMed]

8. Bourgi, J.; Said, J.-M.; Yaakoub, C.; Atallah, B.; Al Akkary, N.; Sleiman, Z.; Ghanimé, G. Bacterial infection profile and predictors among patients admitted to a burn care center: A retrospective study. Burns 2020, 46, 1968-1976. [CrossRef]

9. Norbury, W.; Herndon, D.N.; Tanksley, J.; Jeschke, M.G.; Finnerty, C.C. Infection in Burns. Surg. Infect. 2016, 17, 250-255. [CrossRef] [PubMed]

10. Church, D.; Elsayed, S.; Reid, O.; Winston, B.; Lindsay, R. Burn Wound Infections. Clin. Microbiol. Rev. 2006, 19, 403-434. [CrossRef]

11. Suraiya, S.; Zuraina, N.; Ahmad, F.; Rahman, Z.A. Fatal Wohlfahrtiimonas chitiniclastica Bacteremia in an Immunocompromised Patient. Clin. Microbiol. Newsl. 2017, 39, 172-173. [CrossRef]

12. Gupta, A.K.; Nayduch, D.; Verma, P.; Shah, B.; Ghate, H.V.; Patole, M.S.; Shouche, Y.S. Phylogenetic characterization of bacteria in the gut of house flies (Musca domestica L.). FEMS Microbiol. Ecol. 2012, 79, 581-593. [CrossRef]

13. Matos, J.; Faria, A.R.; Assef, A.P.D.C.; de Freitas-Almeida, Â.C.; Albano, R.M.; Queiroz, M.L.P. Draft Genome Sequence of a Wohlfahrtiimonas chitiniclastica Strain Isolated from Frozen Chicken in Rio De Janeiro, Brazil. Microbiol. Resour. Announc. 2019, 8 , e00352-19. [CrossRef]

14. Sanyal, S.K.; Mou, T.J.; Chakrabarty, R.P.; Hoque, S.; Hossain, M.A.; Sultana, M. Diversity of arsenite oxidase gene and arsenotrophic bacteria in arsenic affected Bangladesh soils. AMB Express 2016, 6, 21. [CrossRef] 
15. Qi, J.; Gao, Y.; Wang, G.-S.; Li, L.-B.; Li, L.-L.; Zhao, X.-M.; Du, Y.-J.; Liu, Y.-Q. Identification of Wohlfahrtiimonas chitiniclastica isolated from an infected cow with hoof fetlow, China. Infect. Genet. Evol. 2016, 41, 174-176. [CrossRef]

16. Sulakova, H.; Gregor, F.; Ježek, J.; Tkoč, M. Nová Invaze Do Našich Obcí a Měst: Koutule Clogmia Albipunctata a Problematika Myiáz. Živa 2014, 1, 29-32.

17. Almuzara, M.N.; Palombarani, S.; Tuduri, A.; Figueroa, S.; Gianecini, R.A.; Sabater, L.; Ramirez, M.S.; Vay, C.A. First Case of Fulminant Sepsis Due to Wohlfahrtiimonas chitiniclastica. J. Clin. Microbiol. 2011, 49, 2333-2335. [CrossRef] [PubMed]

18. Kõljalg, S.; Telling, K.; Huik, K.; Murruste, M.; Saarevet, V.; Pauskar, M.; Lutsar, I. First report of Wohlfahrtiimonas chitiniclastica from soft tissue and bone infection at an unusually high northern latitude. Folia Microbiol. 2015, 60, 155-158. [CrossRef] [PubMed]

19. Suryalatha, K.; John, J.; Thomas, S. Wohlfahrtiimonas chitiniclastica-associated osteomyelitis: A rare case report. Future Microbiol. 2015, 10, 1107-1109. [CrossRef] [PubMed]

20. de Dios, A.; Jacob, S.; Tayal, A.; Fisher, M.A.; Dingle, T.C.; Hamula, C.L. First Report of Wohlfahrtiimonas Chitiniclastica Isolation from a Patient with Cellulitis in the United States. J. Clin. Microbiol. 2015, 53, 3942-3944. [CrossRef]

21. Campisi, L.; Mahobia, N.; Clayton, J.J. Wohlfahrtiimonas chitiniclasticaBacteremia Associated with Myiasis, United Kingdom Emerg. Infect. Dis. 2015, 21, 1068-1069. [CrossRef]

22. Nogi, M.; Bankowski, M.J.; Pien, F.D. Wohlfahrtiimonas chitiniclastica Infections in 2 Elderly Patients, Hawaii, USA. Emerg. Infect. Dis. 2016, 22, 567-568. [CrossRef]

23. Hoffman, R.; Fortuin, F.; Newton-Foot, M.; Singh, S. First report of Wohlfahrtiimonas chitiniclastica bacteraemia in South Africa. S. Afr. Med. J. 2016, 106, 1062. [CrossRef]

24. Schröttner, P.; Rudolph, W.W.; Damme, U.; Lotz, C.; Jacobs, E.; Gunzer, F. Wohlfahrtiimonas chitiniclastica: Current insights into an emerging human pathogen. Epidemiol. Infect. 2017, 145, 1292-1303. [CrossRef] [PubMed]

25. Chavez, J.A.; Alexander, A.J.; Balada-Llasat, J.M.; Pancholi, P. A case of Wohlfahrtiimonas chitiniclastica bacteremia in continental United States. JMM Case Rep. 2017, 4, e005134. [CrossRef] [PubMed]

26. Lysaght, T.B.; Wooster, M.E.; Jenkins, P.C.; Koniaris, L.G. Myiasis-induced sepsis: A rare case report of Wohlfahrtiimonas chitiniclastica and Ignatzschineria indica bacteremia in the continental United States. Medicine 2018, 97, e13627. [CrossRef] [PubMed]

27. Katanami, Y.; Kutsuna, S.; Nagashima, M.; Takaya, S.; Yamamoto, K.; Takeshita, N.; Hayakawa, K.; Kato, Y.; Kanagawa, S.; Ohmagari, N. Wohlfahrtiimonas chitiniclastica Bacteremia Hospitalized Homeless Man with Squamous Cell Carcinoma. Emerg. Infect. Dis. 2018, 24, 1746-1748. [CrossRef]

28. Bonwitt, J.H.; Tran, M.; Dykstra, E.A.; Eckmann, K.; Bell, M.E.; Leadon, M.; Sixberry, M.; Glover, W.A. Fly Reservoir Associated with Wohlfahrtiimonas Bacteremia in a Human. Emerg. Infect. Dis. 2018, 24, 370-373. [CrossRef] [PubMed]

29. Connelly, K.L.; Freeman, E.; Smibert, O.C.; Lin, B. Wohlfahrtiimonas chitiniclastica bloodstream infection due to a maggot-infested wound in a 54-year-old male. J. Glob. Infect. Dis. 2019, 11, 125-126. [CrossRef]

30. Fenwick, A.J.; Arora, V.; Ribes, J.A. Wohlfahrtiimonas chitiniclastica: Two Clinical Cases and a Review of the Literature. Clin. Microbiol. Newsl. 2019, 41,33-38. [CrossRef]

31. Snyder, S.; Singh, P.; Goldman, J. Emerging pathogens: A case of Wohlfahrtiimonas chitiniclastica and Ignatzschineria indica bacteremia. IDCases 2020, 19, e00723. [CrossRef]

32. Bueide, P.; Hunt, J.; Bande, D.; Guerrero, D.M. Maggot Wound Therapy Associated with Wohlfahrtiimonas chitiniclastica Blood Infection. Cureus 2021, 13, e12471. [CrossRef]

33. Geary, M.J.; Russell, R.C.; Hudson, B.J.; Hardy, A. Exotic myiasis with Lund's fly (Cordylobia rodhaini). Med. J. Aust. 1999, 171, 654-655. [CrossRef] [PubMed] 